\title{
FENOMENA TANGGAP LABA INVESTOR: studi Pada Sektor Properti di Bursa Efek Indonesia.
}

\author{
Hendang Tanusdjaya (hendangt@ fe.untar.ac.id) \\ Ishak Ramli (ishakr@ fe.untar.ac.id) \\ Dept. Akuntansi, Fakultas Ekonomi, Universitas Tarumanagara
}

\begin{abstract}
Abstrak
Tanggap laba pemegang saham terhadap informasi laba masih belum konsisten. Studi ini bertujuan memberikan bukti empiris dan kajian terhadap reaksi pemegang saham terhadap informasi laba yang dipublikasikan. Dengan menggunakan data perusahaan properti yang tercatat di Bursa Efek Indonesia berdasarkan informasi yang dipublikasikan selama tahun 2010 sampai dengan 2014, data dianalisis menggunakan Analisis General Linear Model guna menguji pengaruh Corporate Governance dengan dimensinya, leverage, dan profitabilitas terhadap koefisien tanggap laba (earnings response coefficient). Hasilnya bahwa tanggap laba pemegang saham sektor properti terhadap informasi Good Corporate Governance (GCG) sangat lemah karena masih lemahnya praktek implementasi $G C G$ di Indonesia sehingga sinyal/informasi implementasi $G C G$ belum dapat menggerakkan pihak investor (principal) untuk memberikan respons terhadap informasi laba yang disampaikan oleh agen. Demikian juga terhadap informasi besarnya utang tanggap laba pemegang saham sangat lemah bahkan terhadap informasi profitabilitas tidak di tanggapi pemegang saham. Temuan menarik bahwa pemegang saham sektor properti sebagian besar pemegang saham jangka pendek yang lebih melihat risiko dalam investasi pada saham sektor properti ini.
\end{abstract}

Kata kunci: Earning response coefficient (ERC), Good Corporate Governance, leverage, profitabilitas.

\section{PENDAHULUAN}

Pada teori Efficient Market Hypothesis (EMH) investor yang rasional menggunakan semua informasi yang mereka miliki atau yang dapat mereka peroleh, baik berupa informasi yang telah diketahui (known information) maupun kepercayaan (belief) dalam menentukan harga saham dan menjadi topik utama penelitian akuntansi yang menarik sejak Ball dan Brown (1968). Hipotesis pasar yang efisien mengasumsikan bahwa harga pasar sekuritas saat ini merefleksikan semua informasi yang terkandung di dalamnya. Dalam memahami hipotesis pasar efisien, Fama (1970: 383) membaginya ke dalam 3 bentuk yakni 1) Weak Form, kondisi dimana harga saham yang terbentuk dipasar mencerminkan data historis (volume perdagangan masa lalu), 2) Semistrong Form, kondisi dimana harga pasar yang terbentuk telah mencerminkan mengenai data historis dan informasi publik, dan 3) Strong Form, kondisi dimana harga pasar yang terbentuk telah mencerminkan mengenai data historis, informasi publik, dan informasi non publik.

Pada saat pengumuman laba (accounting information) berlangsung, pasar diharapkan untuk bereaksi karena investor melakukan koreksi baik atas ekspetasi risk and return mereka sebagai akibat adanya perbedaan ekspetasi laba/rugi oleh investor dengan laba/rugi akuntansi yang diumumkan (unexpected change in earnings). Dampak perubahan unexpected change in earnings terhadap harga saham ini diukur melalui koefisien respons laba (Earnings Response Coefficient). Pengaruh reaksi pasar terhadap unexpected change in earnings ini tidak selalu konstan melainkan bervariasi baik antar perusahaan, variabel pengujian maupun periode pengujian. Perbedaan cross sectional ini kemudian dimanfaatkan oleh para peneliti untuk menguji berbagai fenomena (misal pengumuman dividen, merger dan akuisisi, penerapan standar akuntansi baru, dsb) terhadap Earnings Response Coefficient (ERC). Akibat perbedaan cross sectional, hubungan antara $E R C$ dan antar variabelnya tidaklah sepenuhnya diketahui sehingga belum dapat ditemukan perlakuan yang tepat termasuk perlakuan $E R C$ di Indonesia. Oleh karena itu, penting untuk menguji dan menganalisis faktor-faktor penentu $E R C$ dalam lingkungan dan waktu yang berbeda. Disamping itu beberapa faktor/variabel diidentifikasi berpengaruh signifikan terhadap $E R C$, diantaranya: risiko sistematis (Easton dan Zmijweski, 1989; Collins \& Kothari, 1989; Lipe, 1990), growth (Collins \& Kothari, 1989), earnings persistence (Kormendi \& Lipe, 1987; Collins \& Kothari, 1989), size (Collins, Kothari \& Rayburn, 1987), dan leverage (Dhaliwal, Lee \& Fargher, 1991). Good Corporate Governance $(G C G)$ dalam literatur juga memperbaiki kepercayaan investor dan mempengeruhi ERC .

Sementara itu jumlah komite audit, independensi, dan aktivitas (jumlah rapat) Dewan Direksi dan proporsi Dewan Komisaris independen berpengaruh positif terhadap ERC (Anderson et al., 2003). Namun dalam blockholders, kepemilikan manajerial oleh Dewan Komisaris, kompetensi komite audit, dan 
leverage tidak berpengaruh terhadap ERC (Bugshan, 2005). Adapun untuk kepemilikan manajerial oleh Dewan Direksi berpengaruh negatif terhadap ERC serta ukuran Dewan Direksi yang besar dan independensi komite audit berpengaruh positif terhadap ERC. Warfield et al. (1995) dalam Gabrielsen et al. (2002) menemukan bahwa kepemilikan manajerial berpengaruh positif terhadap ERC pada pasar modal Amerika Serikat. Hasil sebaliknya dikemukakan oleh Gabrielsen et al. (2002) pada pasar modal Denmark yang mencatat kepemilikan manajerial berpengaruh negatif terhadap ERC. Teoh dan Wong (1993) mencatat bahwa kualitas audit berpengaruh terhadap ERC, perusahaan yang diaudit oleh Big Eight (sekarang Big Four) memiliki ERC yang lebih besar dibanding perusahaan yang diaudit oleh Non Big Eight. Hasil sebaliknya ditunjukkan oleh Kabir et al. (2011) yang menemukan bahwa kualitas audit tidak berpengaruh terhadap kualitas laba yang dapat diukur melalui ERC.

Blockholders, kepemilikan asing (foreign share ownership), dan duality (dummy variable 1 jika perusahaan mengadopsi one tier system, 0 sebaliknya) mempengaruhi ERC, sedangkan kepemilikan oleh negara (state ownership), kepemilikan oleh swasta nasional (legal share ownership), board composition, ukuran Dewan Direksi (board size), dan paid chairman tidak berpengaruh terhadap ERC (Firth et al., 2006). Dimensi kualitas audit, board independent, independensi komite audit, kompetensi komite audit, dan kepemilikan manajerial sebagai variabel $G C G$ berpengaruh positif terhadap ERC (Zakaria, 2012).

Adapun pengaruh komponen non-GCG terhadap ERC juga belum konsisten. Ukuran perusahaan (size) tidak berpengaruh terhadap Earnings Response Coefficient, earnings persistence berpengaruh positif, dan risiko sistemastis (beta) berpengaruh negatif (Easton dan Zmijweski, 1989), sedangkan growth berpengaruh positif terhadap ERC (Collins dan Kothari, 1989). Earnings persistence berpengaruh negatif terhadap ERC karena kehadiran komponen transitory pada pendapatan tahunan (Ali dan Zarowin, 1992). Default risk of debt yang diukur melalui rating obligasi berpengaruh negatif terhadap ERC (Dhaliwal dan Reynolds, 1994). Sedangkan Billings (1999) mwncatat default risk of debt tidak berpengaruh terhadap ERC. Leverage (financial maupun opreating) berpengaruh negatif terhadap ERC (Dhaliwal et al., 1991; Dhaliwal \& Reynolds, 1994; Biddie dan Show, 1991). Sedangkan Bugshan (2005) menyimpulkan bahwa leverage tidak berpengaruh terhadap ERC. Sementara Moradi (2010) dan Farooque et al. (2013) mencatat leverage berhubungan positif terhadap ERC. Burgstahler \& Dichev (1997) dan Hasanzade et al. (2013) menyimpulkan bahwa profitabilitas berpengaruh positif terhadap ERC. Sedangkan Zhang, G. (2013) menemukan bahwa profitablitas dapat berpengaruh positif maupun negatif terhadap ERC tergantung kepada kondisi industri saat dilakukan penelitian (industry-wide events).

Tipe produk, dan barriers to entry berpengaruh positif terhadap ERC (Biddie dan Show, 1991). Competition, cost structure, dan growth berpengaruh terhadap ERC (Ahmed, 1994). Informasi laba lebih berpengaruh terhadap ERC dibanding informasi rugi (Hayn, 1995) sementara Martikainen (1997) menemukan informasi rugi yang berpengaruh terhadap ERC bergantung pada tingkat pertumbuhan (growth) dan financial leverage.

$E R C$ pada perusahaan yang banyak menggunakan jasa nonaudit (dari KAP yang sama) lebih kecil dibandingkan perusahaan yang menggunakan jasa nonaudit secara minimal (Francis dan Ke, 2006). Nilai ERC menurun secara signifikan untuk perusahaan yang terbukti melakukan backdating oleh SEC dan ketika perusahaan menerbitkan (issue) obligasi (Cheng et al., 2008; Yohan An, 2015) dan sebaliknya ERC meningkat ketika perusahan melakukan penebusan (redemption) atas obligasi. ERC perusahaan yang menerima analisa positif dari para analis terkait prediksi laba dimasa mendatang, lebih besar dibanding entitas yang menerima analisa negative (Imhoff, 1992). Earnings forecasts yang dikeluarkan oleh pihak manajemen berpengaruh positif terhadap ERC karena earnings forecasts dapat mengurangi asimetri informasi (Lennox dan Park, 2006). Dan kenaikan Research \& Development $(R \& D)$ costs berpengaruh negatif terhadap ERC (Lev dan Zarowin, 1999).

Dari berbagai literatur tersebut ditemukan masih belum konsisten perlakuan $G C G$ terhadap $E R C$, sehingga masih perlu dilakukan penelitian kembali terhadap faktor-faktor yang mempengaruhi $E R C$ dalam hubungannya dengan $G C G$.

Penelitian ini melanjutkan penelitian-penelitian sebelumnya dan bertujuan mengevaluasi faktorfaktor yang belum konsisten mempengaruhi ERC. Variabel Good Corporate Governance (GCG), meliputi kualitas audit, blockholders, kepemilikan manajerial-dewan direksi, dan kepemilikan manajerial-dewan 
komisaris. dan variabel non $G C G$, yang masih belum konsistem adalah leverage dan profitabilitas. Masih jadi pertanyaan penelitian apakah good corporate governance (kualitas audit, blockholders kepemilikan manajerial-dewan direksi, kepemilikan manajerial-dewan komisaris), leverage, dan profitabilitas mempengaruhi ERC?

\section{METODE PENELITIAN}

Penelitian ini dikategorikan sebagai penelitian kuantitatif, dan merupakan causal study (hubungan sebab akibat) bertujuan untuk mengkaji bagaimana satu variabel mempengaruhi, atau "bertanggungjawab atas" perubahan yang terjadi pada variabel lain (Cooper \& Schindler, 2006: 176). Penelitian ini menggunakan metode penelitian data panel.

\section{Populasi dan Teknik Pemilihan Sampel}

Subyek penelitian adalah seluruh perusahaan publik yang terdaftar di Bursa Efek Indonesia (BEI) dengan periode pengamatan mulai dari tahun 2010 sampai dengan 2014. Sampel penelitian adalah perusahaan properti yang terdaftar di BEI selama periode pengamatan tahun 2010 sampai dengan 2014. Perusahaan properti diambil karena dalam mengembangkan bisnisnya, umumnya perusahaan properti menggunakan sumber pendanaan dari utang sehingga memiliki tingkat rasio Debt to Equity (DER) yang tinggi. Dengan adanya mekanisme corporate governance, perusahaan properti diharapkan dapat tetap memperoleh reaksi positif pada saat pengumuman laba dari para investor walaupun memiliki tingkat rasio DER yang tinggi. Untuk mengukur reaksi pasar (investor) terhadap informasi akuntansi (laba) dapat menggunakan koefisien respons laba.

\section{Earnings Response Coefiient (ERC)}

Cho dan Jung (1991) dalam Arfan dan Antasari (2008: 51) merumuskan koefisien respon laba (ERC) sebagai pengaruh laba kejutan (unexpected earnings) terhadap Cumulative Abnormal Return $(C A R)$, yang ditunjukkan melalui slope coeficient dalam regresi abnormal return saham dengan unexpected earnings. Dengan menggunakan model yang dikembangkan oleh Teets dan Wasley (1996) dalam Suaryana (2008: 10), ERC dapat dirumuskan sebagai berikut:

$$
\mathrm{CAR}_{\mathrm{it}}=\alpha_{0}+\alpha_{1} \mathrm{UE}_{\mathrm{it}}+\varepsilon_{\mathrm{it}}
$$

CAR $R_{\mathrm{it}} \quad=$ Cumulative Abnormal Return atau abnormal return kumulatif perusahaan i selama periode pengamatan \pm 5 hari dari publikasi laporan keuangan

$U E_{\mathrm{it}} \quad=$ Unexpected Earnings

$\alpha_{1} \quad=$ Earnings Response Coefficient

$\varepsilon_{\mathrm{it}} \quad=$ Komponen error dalam model atas perusahaan i pada periode $\mathrm{t}$

\section{Cumulative Abnormal Return (CAR)}

$C A R$ merupakan akumulasi return tidak normal kumulatif sekuritas perusahaan i selama periode 5 hari sebelum dan 5 hari sesudah tanggal publikasi laba. $C A R$ dirumuskan sebagai berikut:

$$
\mathrm{CAR}_{\mathrm{i}(-5,+5)}=\mathrm{t}=-5^{+5} \mathrm{AR}_{\mathrm{it}}
$$

$C A R_{\mathrm{i}(-5,+5)}=$ abnormal return kumulatif perusahaan i selama periode pengamatan kurang lebih 11 hari dari tanggal publikasi laporan keuangan. (5 hari sebelum, 1 hari tanggal publikasi dan 5 hari setelah tanggal penyerahan laporan keuangan ke Bapepam)

$A R_{\mathrm{it}} \quad=$ abnormal return perusahaan i pada hari $\mathrm{t}$

$$
\mathrm{AR}_{\mathrm{i}, \mathrm{t}}=\mathrm{R}_{\mathrm{i}, \mathrm{t}}-\mathrm{R}_{\mathrm{m}, \mathrm{t}}
$$

$\mathrm{R}_{\mathrm{i}, \mathrm{t}} \quad=$ Return perusahaan pada periode ke- $\mathrm{t}$

$\mathrm{R}_{\mathrm{m}, \mathrm{t}} \quad=$ Return pasar pada periode ke- $\mathrm{t}$

Abnormal return, berasal dari return saham harian dan return pasar harian.

Return saham harian dihitung dengan rumus:

$$
R_{i t}=\frac{\mathbf{P}_{i t}-P_{i t-1}}{P_{i t-1}}
$$


$\begin{array}{ll}\mathrm{R}_{\mathrm{it}} & =\text { Return saham perusahaan } \mathrm{i} \text { pada hari } \mathrm{t} \\ \mathrm{P}_{\mathrm{it}} & =\text { Harga penutupan saham } \mathrm{i} \text { pada hari } \mathrm{t} \\ \mathrm{P}_{\mathrm{it}-1} & =\text { Harga penutupan saham } \mathrm{i} \text { pada pada hari } \mathrm{t}-1\end{array}$

Return pasar harian dihitung sebagai berikut:

$$
R m_{t}=\frac{\left(H S G_{t}-I H S G_{t-1}\right.}{I H S G_{t-1}}
$$

$\begin{array}{ll}\mathrm{Rm}_{\mathrm{t}} & =\text { Return pasar harian } \\ \mathrm{IHSG}_{\mathrm{t}} & =\text { Indeks Harga Saham Gabungan pada hari } \mathrm{t} \\ \mathrm{IHSG}_{\mathrm{t}-1} & =\text { Indeks Harga Saham Gabungan pada hari } \mathrm{t}-1\end{array}$

\section{Unexpected Earnings (UE)}

Unexpected Earnings (UE) dapat dirumuskan sebagai selisih antara laba sesungguhnya dengan laba ekspektasian dimana untuk laba ekspektasian diestimasi dengan model langkah acak (random walk model) seperti yang tertuang pada penelitian Beaver dan Ryan (1987) serta Collins dan Kothari (1989) dalam Arfan dan Anatasari (2008: 56) yang dijabarkan sebagai berikut:

$$
U E_{i t}=\frac{E_{i t}-E_{i t-1}}{\left|E_{i t-1}\right|}
$$

$U E_{\text {it }} \quad=$ Unexpected Earnings perusahaan i pada tahun $\mathrm{t}$

$\mathrm{E}_{\mathrm{it}} \quad=$ Laba akuntansi perusahaan i pada periode $\mathrm{t}$

$\mathrm{E}_{\mathrm{it}-1} \quad=$ Laba akuntansi perusahaan i pada periode $\mathrm{t}-1$

Kualitas audit

Kualitas audit sejalan dengan hasil penelitian Teoh dan Wong (1993: 355) diukur dengan menggunakan variabel dummy: 1 jika laporan keuangan diaudit oleh KAP Big 4 dan 0 jika laporan keuangan diaudit oleh KAP non Big 4.

\section{Blockholders}

Blockholders sesuai penelitian Shleifer dan Vishny (1997) dalam Setyaningrum (2005: 83) didefinisikan sebagai jumlah investor yang memiliki jumlah kepemilikan saham yang besar (10\%-20\%). Untuk penelitiannya, penulis menggunakan nilai kepemilikan sebesar 5\% sesuai Lampiran Surat Edaran Otoritas Jasa Keuangan Nomor 32 /SEOJK.04/2015 tentang Pedoman Tata Kelola Perusahaan Terbuka.

1. Kepemilikan manajerial-dewan direksi

Skaife et al. (2014: 11) merumuskan kepemilikan manajerial-dewan direksi sebagai persentase saham yang dimiliki oleh Dewan Direksi dibagi dengan jumlah saham yang beredar.

2. Kepemilikan manajerial-dewan komisaris

Beasley (1996: 453-454) merumuskan kepemilikan manajerial-dewan komisaris sebagai persentase saham yang dimiliki oleh Dewan Komisaris dibagi dengan jumlah saham yang beredar.

\section{Leverage}

Leverage pada penelitian ini diukur dengan menggunakan rasio Debt to Equity Rato (DER) yang dapat dihitung dengan rumus sebagai berikut:

DER $=\frac{\text { Total Debt }}{\text { Total Equity }} \times 100 \%$

4. Profitabilitas

Profitabilitas perusahaan dalam penelitian ini menggunakan rasio Return on Equity (ROE) yang dapat dihitung dengan rumus sebagai berikut: 


$$
R O E=\frac{\text { Net profit After Tax }}{\text { Equity }} \times 100 \%
$$

\section{Analisis Data}

Teknik analisis data digunakan analisis General Linear Model (GLM). Dalam melakukan analisis penghitungan untuk kedua prosedur di atas, digunakan perangkat lunak program IBM SPSS Statistics versi 22.

Model penelitian 1:

$\mathrm{ERC}=\beta_{0}+\beta_{1}$ AUDITQ $+\beta_{2}$ BLOCK $+\beta_{3}$ DIR $+\beta_{4} \mathrm{KOM}+\varepsilon$

Keterangan:

$\begin{array}{ll}\text { ERC } & =\text { Earnings Response Coefficient }(\text { ERC }) \\ \text { AUDITQ } & =\text { Kualitas audit } \\ \text { BLOCK } & =\text { Blockholders } \\ \text { DIR } & =\text { Kepemilikan manajerial-dewan direksi } \\ \text { KOM } & =\text { Kepemilikan manajerial-dewan komisaris } \\ \mathrm{B}_{0} & =\text { Intercept } \\ \beta_{1} \ldots \ldots . . . \beta_{6} & =\text { Koefisien Regresi }\end{array}$

Model penelitian 2:

$\mathrm{ERC}=\beta_{02}+\beta_{12}$ AUDITQ $+\beta_{22}$ BLOCK $+\beta_{32}$ DIR $+\beta_{42}$ KOM $+\beta_{52}$ LEV $+\beta_{62}$ PROF $+\varepsilon$

Keterangan:

$\begin{array}{ll}\text { ERC } & =\text { Earnings Response Coefficient }(\text { ERC }) \\ \text { AUDITQ } & =\text { Kualitas audit } \\ \text { BLOCK } & =\text { Blockholders } \\ \text { DIR } & =\text { Kepemilikan manajerial-dewan direksi } \\ \text { KOM } & =\text { Kepemilikan manajerial-dewan komisaris } \\ \text { LEV } & =\text { Leverage } \\ \text { PROF } & =\text { Profitabilitas } \\ \mathrm{B}_{0} & =\text { Intercept } \\ \beta_{12 \ldots \ldots . . . . . .} \beta_{62} & =\text { Koefisien Regresi }\end{array}$

\section{HASIL PENELITIAN DAN PEMBAHASAN}

Sampel yang digunakan adalah sebanyak 40 Perusahaan property selama tahun 2010-2014.

Tabel 1.

Parameter Estimates Model Penelitian 1

\begin{tabular}{|c|c|c|c|c|c|c|c|}
\hline \multirow[t]{2}{*}{ Parameter } & \multirow[t]{2}{*}{ B } & \multirow[t]{2}{*}{ Std. Error } & \multirow[t]{2}{*}{$\mathrm{t}$} & \multirow[t]{2}{*}{ Sig. } & \multicolumn{2}{|c|}{$\begin{array}{l}\text { 95\% Confidence } \\
\text { Interval }\end{array}$} & \multirow[t]{2}{*}{$\begin{array}{l}\text { Partial Eta } \\
\text { Squared }\end{array}$} \\
\hline & & & & & $\begin{array}{l}\text { Lower } \\
\text { Bound }\end{array}$ & $\begin{array}{l}\text { Upper } \\
\text { Bound }\end{array}$ & \\
\hline Intercept & -.053 & .144 & -.370 & .712 & -.337 & .230 & .001 \\
\hline AUDITQ & .070 & .165 & .422 & .674 & -.256 & .395 & .001 \\
\hline BLOCK & .147 & .071 & 2.090 & .038 & .008 & .287 & .022 \\
\hline DIR & .295 & .122 & 2.424 & .016 & .055 & .534 & .029 \\
\hline KOM & -.155 & .123 & -1.265 & .207 & -.397 & .087 & .008 \\
\hline
\end{tabular}

Sumber: hasil olah data menggunakan IBM SPSS Statistics versi 22.

Model Penelitian 1:

Hanya Blockholders dan Kepemilikan manajerial-dewan direksi (GCG Factors) yang signifikan positip mempengaruhi ERC, kualitas audit Kepemilikan manajerial-dewan komisaris (GCG Factors), tidak signifikan positip mempengaruhi ERC. Pengaruh Blockholders dan kepemilikan manajerial (direksi) 0,051 atau 5,51\% mempengaruhi ERC. 
Tabel 2

Parameter Estimates Model Penelitian 2

\begin{tabular}{|c|c|c|c|c|c|c|c|}
\hline \multirow[b]{2}{*}{ Parameter } & \multirow[b]{2}{*}{ B } & \multirow[b]{2}{*}{ Std. Error } & \multirow[b]{2}{*}{$\mathrm{t}$} & \multirow[b]{2}{*}{ Sig. } & \multicolumn{2}{|c|}{$\begin{array}{l}\text { 95\% Confidence } \\
\text { Interval }\end{array}$} & \multirow[b]{2}{*}{$\begin{array}{c}\text { Partial Eta } \\
\text { Squared }\end{array}$} \\
\hline & & & & & $\begin{array}{l}\text { Lower } \\
\text { Bound }\end{array}$ & $\begin{array}{l}\text { Upper } \\
\text { Bound }\end{array}$ & \\
\hline Intercept & .015 & .145 & .104 & .918 & -.270 & .300 & .000 \\
\hline AUDITQ & -.020 & .167 & -.118 & .907 & -.348 & .309 & .000 \\
\hline BLOCK & .181 & .071 & 2.554 & .011 & .041 & .321 & .033 \\
\hline DIR & .302 & .120 & 2.511 & .013 & .065 & .539 & .032 \\
\hline KOM & -.202 & .123 & -1.645 & .101 & -.444 & .040 & .014 \\
\hline LEV & -.187 & .078 & -2.404 & .017 & -.340 & -.034 & .029 \\
\hline PROF & -.003 & .074 & -.037 & .971 & -.149 & .144 & .000 \\
\hline
\end{tabular}

Sumber: hasil olah data menggunakan IBM SPSS Statistics versi 22.

Model penelitian 2

Blockholders, kepemilikan manajerial dewan direksi, dan leverage signifikan positip mempengaruhi ERC dan pengaruhnya sebesar $0,094(0,033+0,032+0,029)$ atau $9,40 \%$ mempengaruhi ERC. Sementara kualitas audit, kepemilikan manajerial dewan komisaris tidak signifikan positip mempengaruhi ERC.

\section{Koefisien Determinasi $\left(\mathbf{R}^{2}\right)$}

Besarnya nilai $R$-squared untuk model penelitian 1 dan 2 masing-masing sebesar 0,063 dan 0.094 dan nilai adjusted $R$-squared untuk model penelitian 1 dan 2 masing-masing sebesar 0,044 dan 0.066. ERC 90,6\% dapat dijelaskan oleh variabel lain yang tidak dimasukkkan ke dalam penelitian ini, seperti ukuran Dewan Direksi, independensi Dewan Direksi, aktivitas (jumlah rapat) Dewan Direksi, proporsi Dewan Komisaris independen, kompetensi komite audit, independensi komite audit, foreign share owneship, duality, state ownership, legal share ownership, komposis direksi, paid chairman, beta, growth, size, earnings persistence, default risk of debt, tipe produk, barriers to entry, operating leverage, dan sebagainya.

\section{Pembahasan}

ERC ternyata sangat kecil dipengaruhi oleh GCG, leverage, dan profitabilitas. Pengaruh variabel good corporate governance yang diwakili oleh dimensi: 1) kualitas audit, 2) blockholders, 3) kepemilikan manajerial-dewan direksi, dan 4) kepemilikan manajerial-dewan komisaris secara simultan signifikan, namun sangat lemah terhadap ERC. Hal mencerminkan masih lemahnya praktek implementasi $G C G$ di Indonesia sehingga sinyal/informasi implementasi $G C G$ belum dapat menggerakkan pihak investor (principal) untuk memberikan respons terhadap informasi laba yang disampaikan oleh agen. Herwidiyatmo dalam Setyaningrum (2005) menggaris bawahi terdapat beberapa kelemahan penerapan $G C G$ di Indonesia yakni: 1) adanya konsentrasi kepemilikan oleh pihak tertentu yang memungkinkan terjadinya hubungan afiliasi antara pemilik, pengawas, dan direktur perusahaan, 2) tidak efektifnya peran Dewan Komisaris, dan 3) lemahnya penegakan hukum. Setiawan dan Kartikasari (2008: 49) memberikan argumentasi lain bahwa lemahnya pengaruh variabel $G C G$ terhadap ERC dapat disebabkan oleh penggunaan variabel corporate governance yang tidak menangkap mekanisme corporate governance sebagai satu kesatuan dimana variabel corporate governance tidak diukur melalui indeks tertentu, melainkan melalui variabelvariabel yang terpisah.

Variabel good corporate governance yang diwakili oleh dimensi: 1) kualitas audit, 2) blockholders, 3) kepemilikan manajerial-dewan direksi, dan 4) kepemilikan manajerial-dewan komisaris serta variabel leverage dan profitabilitas mempengaruhi ERC secara simultan signifikan. Sejalan dengan Firth et al. (2006) dan Zakaria (2012). Investor memberi respons yang lebih positif apabila informasi $G C G$ dikombinasikan dengan informasi non-GCG oleh agent. Melalui kombinasi faktor $G C G$ dan non-GCG, investor merasa lebih percaya diri dalam berinvestasi pada instrumen saham sehingga meningkatkan respons investor terhadap informasi nilai laba yang diukur melalui koefisien $E R C$.

\section{KESIMPULAN}


Praktek GCG, leverage, dan profitabilitas belum mendapat tanggapan positif dari pemegang saham property dalam menentukan return yang diukur dengan ERC. Pemegang saham belum menggunakan signal positif dan negatif terhadap informasi yang dipublikasikan. Investor lebih banyak menggunakan analisis tehnikal dalam merespons nilai pasar saham. Pemegang saham di pasar modal Indonesia khusus nya pada sector property belum melihat nilai perusahaan dari operasi GCG, mengingat sector industry ini memiliki risiko cukup besar sehingga lebih memilih investasi jangka pendek saja. Pemegang saham sector property lebih dominan pemegang saham trader.

Penggunaan hutang masih dilihat pemegang saham sebagai risiko dari leverage sehingga direspons negatif. Temuan yang menarik adalah profitabilitas, kualitas audit tidak ditanggapi atau tidak menjadi bahan pertimbangan meresponi pembelian saham sektor properti. Hal ini menambah keyakinan bahwa pemegang saham sektor properti adalah pemegang saham jangka pendek.

\section{DAFTAR PUSTAKA}

Agrawal, A. and Knoeber, C. R. (1996) Firm performance and mechanisms to control agency problems between managers and shareholders, Journal of Financial and Quantitative Analysis, 31(3), September, 377-397.

Ahmed, A. (1994). Accounting earnings and future economic rents: An empirical analysis. Journal of Accounting and Economics 17, 377-400

Ali, A. \& Zarowin, P. (1992). Permanent vs. transitory components of annual earnings and estimation error in earning response coefficients. Journal of Accounting and Economics, 15, 249-64

Anderson, K., Deli, D., \& Gillan, S. (2003). Boards of directors, audit committees, and the information content of earnings. Retrieved from http://papers.ssrn.com/sol3/papers.cfm?abstract_id=444241

Arfan, M., \& Antasari, I. (2008). Pengaruh ukuran, pertumbuhan, dan profitabilitas perusahaan terhadap koefisien respon laba pada emiten manufaktur di bursa efek jakarta. Jurnal Telaah \& Riset Akuntansi Vol. 1, No. 1. Januari 2008, Hal. 50-64.

Ashbaugh, H., Collins, D.W., \& LaFond, R. (2004). Corporate governance and the cost of equity capital. SSRN Working Paper

Ball, R., \& Brown, P. (1968). An empirical evaluation of accounting income numbers. Journal of Accounting Research Vol 6: 159-177.

Barth, M. (1991). Relative measurement errors among alternative pension asset and liability measures. The Accounting Review, Vol. 66, pp. 433-463.

Barth, M. (1994). Fair value accounting: evidence from investment securities and the market valuation of banks. The Accounting Review, Vol. 69, pp. 1-25.

Barth, M., Beaver, W., \& Landsman, W. (1996). Value-relevance of banks' fair value disclosures under SFAS 107. The Accounting Review, Vol. 71, pp. 513-537.

Beasley, M. (1996). An empirical analysis of the relation between the board of director composition and financial statement fraud. Accounting Review 71: 443-465.

Beaver, W.H., Lambert, R.A., \& Ryan, S.G. (1987). The information content of security prices. Journal of Accounting and Economics Vol 9, Issue 2, July 1987, 139-157

Beaver W., (2002). Perspectives on recent capital market research. Accounting Review 77,453-474.

Billings, B. (1999). Revisiting the relation between the default risk of debt and the earnings response coefficient. The Accounting Review, 74(4), 509-522.

Bugshan, T. (2005). Corporate governance, earnings management, and the information content of accounting earnings: theoretical model and empirical tests. Retrieved from epublications.bond.edu.au

Burgstahler, D.C., \& Dichev, I. (1997). Earnings, Adaptation, and Equity Value. The Accounting Review 72: $187-215$.

Cheffins, B. R. (2003) Will executive pay globalise along American lines?, Corporate Governance: An International Review, 11(1), January, 8-24. 
Cheng, X., Crabtree, A. D., \& Smith, D. B. (2008). The effects of backdating on earnings response coefficients. Working Paper, University of Nebraska-Lincoln.

Cho, J.Y., \& Jung, K. (1991). Earnings response coefficient: A synthesis of theory and empirical evidence. Journal of Accounting Literature 10, 85-116.

Choi, B., Collins, D., \& Johnson, W. (1997). Valuation implications of reliability differences: the case of nonpension postretirement obligations. The Accounting Review, Vol. 72: pp. 351-383.

Chtourou, S., Bedard, J., \& Courteau, L. (2001), Corporate governance and earnings management. Retrieved from http://papers.ssrn.com/sol3/papers. cfm?abstract_id=275053

Collins, D.W., Kothari, S.P., \& Rayburn, J.D. (1987). Firm size and the information content of prices with respect to earnings. Journal of Accounting and Economics 9(2): 111-138

Collins, D., \& Kothari, S. (1989). An analysis of the cross-sectional and intertemporal determinants of earnings response coefficients. Journal of Accounting and Economics 11, 143-181.

Dechow, P., \& Sloan, R. (1991). Executive incentives and the horizon problem: an empirical investigation. Journal of Accounting and Economics (14):51-89.

Dechow, P., Sloan, R., \& Sweeney, A. (1996). Causes and consequences of earnings manipulation: an analysis of firms subject to enforcement actions by the SEC. Contemporary Accounting Research 13, 1-36.

Dechow, P., Ge, W., \& Schrand, C. (2010). Understanding earnings quality: A review of the proxies, their determinants and their consequences. Retrieved from:https://www.researchgate.net/publication/222399742_Understanding_Earnings_Quality_A_Re view_of_the_Proxies_Their_Determinants_and_Their_Consequences.

Dhaliwal, D., Lee, K., \& Fargher, N. (1991). The association between unexpected earnings and abnormal security returns in the presence of financial leverage. Contemporary Accounting Research 8(1): 20 41.

Dhaliwal, D., \& Reynolds, S. (1994). The effect of the default risk of debt on the earnings response coefficient. The Accounting Review, 69(2), 412-419.

Easton, P.D., \& Zmijewski, E. (1989). Cross-sectional variation in the stock market response to accounting earnings announcements. Journal of Accounting and Economics 11, 117-141.

Easton, P., Harris, T., \& Ohlson, J. (1992). Aggregate accounting earnings can explain most of security returns. Journal of Accounting and Economics, Vol. 15, pp. 119-142.

Fama, E., Fisher, L, Jensen, M., \& Roll, R. (1969). The adjustment of stock prices to new information. International Economic Review 10, 1-21.

Fama, E. (1970). Efficient capital markets: a review of theory and empirical work. The Journal of Finance 25, 383-417.

Fama, E. (1991). Efficient capital markets: II. The Journal of Finance 46: 1575-1617.

Fan, J.P.H., \& T.J. Wong, (2002). Corporate ownership and the informativeness of accounting earnings in East Asia, Journal of Accounting and Economics, 33, 401-425.

Farooque, O., Suyono, E., \& Rosita, U. (2013). Link between market return, governance and earnings management: an emerging market perspective. Retrieved from http://ssrn.com/abstract=2316121

Firth, M., Fung, P.M., \& Rui, O. (2006). Ownership, board structure, and the informativeness of earningsevidence from an emerging market. Retrieved from http://papers.ssrn.com/sol3/papers.cfm?abstract_id=167353.

Francis, J. R., Maydew E.L., \& Sparks, H.C. (1999). The role of big 6 auditors in the credible reporting of accruals. Auditing: A Journal of Practice \& Theory 18 (Fall): 17-34.

Francis, J., \& Ke, B., (2006). Disclosure of fees paid to auditors and the market valuation of earnings surprises. Review of Accounting Studies 11, 495-523.

Francis, J., \& Wang, D., (2008). The joint effect of investor protection and big 4 audits on earnings quality around the world. Contemporary Accounting Research 25, 157-191. 
Francis, J. R., \& Yu, M. D. (2009). Big 4 office size and audit quality. The Accounting Review, 84(5), 1521-1552.

Gabrielsen, G., Gramlich, J., \& Plenborg, T. (2002). Managerial ownership, information content of earnings, and discretionary accruals in a non-US Setting, Journal of Business Finance and Accounting, Vol. 29, Issue, 7/8, Sept/Oct. 2002, 967-988.

Ghosh, A., Gu, Z., \& Jain, P. C. (2005). Sustained earnings and revenue growth, earnings quality, and earnings response coefficients. Review of Accounting Studies, 10(1), 33-57.

Harris, M., \& Raviv, A. (1990) Capital structure and the informational role of debt. The Journal of Finance, Vol. 45, No. 2. (Jun.), pp. 321-349.

Hasanzade, M., Darabi, R., \& Mahfoozi, G. (2013). Factors affecting the earnings response coefficient: an empirical study for iran. European Online Journal of Natural and Social Sciences 2013 Vol.2, No.3 Special Issue on Accounting and Management.

Hayn, C. (1995). The information content of losses. Journal of Accounting and Economics 20; 125 -153

Hermawan, A.A. (2011). The influence of effective board of commissioners and audit committee on the informativeness of earnings: evidence from indonesian listed firms. Asia Pacific Journal of Accounting and Finance Volume 2 (1), 1-38

Himmelberg, C.P., Hubbard, R.G., \& Palia, D. (1999). Understanding the determinants of managerial ownership and the link between ownership and performance. Journal of Financial Economics 53: 353-384

Howe, J., \& Schlarbaum, G. (1986). SEC trading suspensions: empirical evidence. The Journal of Financial and Quantitative Analysis, Vol 21, No 3, pp 323-333.

Imhoff, E. A. Jr. (1992). The relation between perceived accounting quality and economic characteristics of the firm, Journal of Accounting and Public Policy, 11, 97-118.

Jensen, M., \& W, Meckling. (1976). Theory of the firm: managerial behaviour, agency costs and ownership structure, Journal of Financial Economics, October, V. 3, No. 4, pp. 305-360.

Jensen, M. (1986). Agency costs of free cash flow, corporate finance and takeovers. American Economic Review 76: pp. 323-29.

Jensen, M. (1993). The modern industrial revolution, exit and the failure of internal control systems. The Journal of Finance XLVIII (July): 831 - 880

Kai, H. (2002). Earning response coefficient and default risk in Japanese stock market. Japan: Nigata University Working Paper.

Kabir, H. M., Sharma, D., Islam, M. A., \& Salat, A. (2011). Big 4 auditor affiliation and accruals quality in Bangladesh. Managerial Auditing Journal, 26(2), 161-181.

Kendall, M. G. (1953). The analysis of economic time series, part i: prices. Journal of the Royal Statistical Society. Series A (General), Volume 116, Issue 1, 11-34

Kormendi, R., \& Lipe, R., (1987). Earnings innovations, earnings persistence and stock returns. Journal of Business 60, 323-345.

Kothari, S.P. (2001). Capital markets research in accounting. Journal of Accounting and Economics 31, $105-231$

Kryzanowski, L. (1979). The efficacy of trading suspension: a regulatory action designed to prevent the exploitation of monopoly information. The Journal of Finance, Vol 34, No 5 (Dec), pp 1187-1200

Kwon, S.Y., Lim, C.Y., \& Tan, P.M. (2007). Legal systems and earnings quality: The role of auditor industry specialization. Auditing: A Journal of Practice \& Theory, 26(2), 25-55.

Lennox, C. \& Park, C., 2006. The informativeness of earnings and management's issuance of earnings forecasts. Journal of Accounting and Economics 42, 439-458.

Lev, B. (1989). On the usefulness of earnings and earnings research: lessons and directions from two decades of empirical research. Journal of Accounting Research, Vol. 27, Issue 3, 1989 Supplement, pp. 153-193.

Lev, B. \& Zarowin, P. (1999). The boundaries of financial reporting and how to extend them. Journal of Accounting Research 37, 353-385. 
Li, J. (1994). Ownership structure and board composition: A multi-country test of agency theory predictions. Managerial and Decision Economics, 15, 359-368

Lipe, R. (1990). The relation between stock returns and accounting earnings given alternative information. The Accounting Review, 65(1): 49-71.

Mace, M.L. (1986). Directors: myth and reality. Boston, MA: Harvard Business School Press.

Martikainen, M. (1997). Accounting losses and earnings response coefficients: The impact of leverage and growth opportunities. Journal of Business Finance and Accounting, 24(2), 277-292.

Martikainen, T., \& Kallunki, J.P. (1997). The lead-lag structure of stock returns and accounting earnings. International Review of Financial-Analysis, Vol. 6, Issue 1, pp.37-48.

McMullen, D. (1994). Audit committee quality. Pennsylvania CPA Journal, Vol. 65, June 1994, pp. 18-3

McMullen, D.A., \& Raghunandan, K. (1996). Enhancing audit committee effectiveness. Journal of Accountancy 182 (August): 79-81.

Moradi, M. (2010). A study of the effect of financial leverage on earnings response coefficient throughout income approach: Iranian evidence. International Review of Accounting, Banking and Finance. Vol. 2 No. 2: Page 104-116.

Mulyani, S., Asyik, N.F., \& Andayani, (2007). Faktor-faktor yang mempengaruhi earning respon coefficient pada perusahaan yang terdaftar di bursa efek jakarta. Jurnal Akuntansi dan Auditing Indonesia, Juni 2007.

Murwaningsari, E. (2008). Pengujian simultan: Beberapa faktor yang mempengaruhi earning response coefficient. Simposium Nasional Akuntansi XI Pontianak.

Naimah, Z., \& Utama, S. (2009). Pengaruh ukuran perusahaan, pertumbuhan dan profitabilitas persahaan terhadap koefisien respon laba dan koefisien respon nilai buku ekuitas: studi pada perusahaan manufaktur di bursa efek jakarta. Simposium Nasional Akuntansi IX Padang.

Patton, A., \& J. Baker. (1987). Why do not directors rock the board? Harvard Business Review 65 (November): $10-12$

Penman, S.H. (1991). An Evaluation of Accounting Rate-of-return. Journal of Accounting, Auditing \& Finance 6: 233

Rohaida, B. (2011). The relationship between governance practices, audit quality and earnings management: UK evidence. Retrieved from: http://etheses. dur.ac.uk/1382/

Setiati, F., \& Kusuma, I. W. (2004). Faktor-faktor yang mempengaruhi koefisien respon laba pada perusahaan bertumbuh dan tidak bertumbuh. Simposium Nasional Akuntansi VII Denpasar.

Shleifer, A., \& Vishny, R. (1986). Large shareholders and corporate control. Journal of Political Economy 94: 461-488

Shleifer, A., \& Vishny, R. (1997). A survey of corporate governance. The Journal of Finance, Vol. 52 No. 2 (June), pp 737-783

Spence, M. (1973). Job Market Signaling. The Quarterly Journal of Economics, Vol. 87, No. 3. (Aug.), pp. 355-374

Suaryana, A. (2008). Pengaruh konservatisme laba terhadap koefisien respons laba. Jurnal Akuntansi dan Bisnis Vol. 3, No. 1

Takacs, L. M. (2012). The value relevance of earnings in a transition economy: evidence from romanian stock market. Retrieved from: https://ideas.repec.org/a/alu/journl/v1y2012i14p8.html

Teets, W.R., \& Wasley, C.E. (1996). Estimating earning response coefficients: pooled versus firm specific models. Journal of Accounting and Economics 21: 279-295.

Teoh, S., \& Wong, T. (1993). Perceived auditor quality and the earnings response coefficient. The Accounting Review, Vol. 68, 1993 (April), pp. 346-367

Vafeas, N. (2000). Board structure and the informativeness of earnings. Journal of Accounting and Public Policy, Vol. 19, pp. 139-160

Walsh, J.P., \& Seward, J.K. (1990). On the efficiency of internal and external corporate control mechanisms. The Academy of Management Review Vol. 15, No. 3 (Jul., 1990), pp. 421-458

Warfield, T., Wild, J., \& Wild, K.L. (1995). Managerial ownership, accounting choices, and informativeness of earnings. Journal of Accounting and Economics, Vol. 2, 61-91. 
Watts, R.L., \& Zimmerman, J.L. (1986). Positive accounting theory. Englewood Cliffs, Prentice-Hall: NJ Wild, J. (1994). Managerial accountability to shareholders: Audit committees and the explanatory power of earnings for returns. British Accounting Review, Vol. 26, 1994a, pp. 353-374

Wild, J. (1996). The audit committee and earnings quality. Journal of Accounting, Auditing and Finance, Vol. 11, pp. 247-276.

Xie, B. \& Davidson, W.N., \& DaDalt, P.J. (2001). Earnings management and corporate governance: the roles of the board and the audit committee. Retrieved from http://www.sciencedirect.com/science/article/pii/ S0929119902000068

Yohan An. (2015). Earnings response coefficients and default risk: case of korean firms. International Journal of Financial Research Vol. 6, No. 2

Yosefa, S. \& Wondabio, L.S. Pengaruh CSR disclosure terhadap earning response coefficient (suatu studi empiris pada perusahaan yang terdaftar di Bursa Efek Jakarta). SNA X K-AKPM 08, Makasar: 26-28 Juli 2007.

Zakaria, N.B. (2012). Corporate governance and the relationship between default risk and the earnings response coefficient. Retrieved from http://researcharchive.vuw.ac.nz/handle/10063/2106

Zhang, G. (2013). Accounting information and equity valuation theory, evidence, and applications. Springer Series in Accounting Scholarship

Beaver, W. (1998). Financial Reporting: an accounting revolution (3rd ed.). Upper Saddle River, NJ: Prentice Hall

Cooper, D.R. \& Schindler, P.S. (2006). Metode riset bisnis, Volume 1, Edisi 9. Jakarta: Media Global Edukasi

Gujarati, D. \& Porter, D. C. (2009). Basic econometrics. New York: McGraw-Hill.

Hair, J. F., Black, B., Babin, B., Anderson, R. E., \& Tatham, R. L. (2010). Multivariate data analysis: A global perspective. New Jersey, USA: Pearson Education Inc.

Jones, C.P. (2007). Investment: analysis and management (10th Ed.). New York: John Wiley \& Sons, Inc.

Scott, W. R, (2009). Financial accounting theory $5^{\text {th }}$ edition. Prentice Hall.

Solomon, J.F. (2007). Corporate governance and accountability, (2nd ed.), Wiley: New York.

Cadbury Committee (1992). Report of the committee on the financial aspects of corporate governance. Gee Ltd (Professional Publishing Ltd): London.

Egon Zehnder International. 2000. Corporate governance and the role of the board of directors 